\title{
Evaluation of Self-Employment Development Factors: Latvian Case
}

\author{
Rita Remeikiene, Mykolas Romeris University
}

\begin{abstract}
The factors that have the impact on selfemployment development have been identified and ranked by importance applying method of expert evaluation. Selfemployment start-up is promoted by the increasing demand in foreign markets, export and lack of competences for all activities while the main barriers are unfavourable economics and institutional environment.
\end{abstract}

Keywords - Macroeconomic factors of self-employment, selfemployment, self-employment barriers, self-employment development.

\section{INTRODUCTION}

Entrepreneurial activity is considered to be an important aspect of economic development and growth. This has been on the agenda of all European countries (Barriers of international cooperation for SMEs in Latvia, Estonia, Finland, and Sweden, 2013, p. 4).

With reference to the survey carried out by Eurobarometer (2009), $45 \%$ of Europeans would prefer self-employment to a hired work as their main occupation while $49 \%$ of Europeans would like to do a hired work. The preference to selfemployment largely depends on personal characteristics and such demographic factors as education, entrepreneurial family background, age and so forth. The reasons why particular number of people chooses a hired work are linked with the regular and fixed income earned doing this kind of work as well as with the stability of the position. Self-employment is preferred by the people who seek personal independence, improvement and decision-making freedom. Unfortunately, the main barrier to self-employment start-up is the fear caused by the unfavourable economic situation in the country, complicated tax environment, bureaucracy, corruption, law uncertainty, bankruptcy risk and the risk to lose life-savings. In numerous cases, self-employment is started-up not due to the ambition to achieve ones objectives, but due to the necessity to subsist.

Vejsiu (2011) interprets business establishment as the main factor of market competitiveness, production, demand growth and economic innovativeness. Thus, the majority of the theoretical and empirical studies are aimed at the comprehensive research of self-employment as well as identification of measures to promote this phenomenon.

In modern world, the problems related to unemployment and decreasing employment are proposed to be solved by promoting self-employment as the alternative to a hired work since it enables elimination of the status of the unemployed. Both the self-employment start-up and development to the level of an enterprise with employees are influenced by numerous factors. The results of the previous scientific research (Remeikiene, Startiene, 2011; Startiene, Remeikiene, 2013) showed that political or institutional factors of selfemployment are most important while creating businessfriendly environment. In general sense, they can be classified into two groups: the factors that have positive impact on selfemployment (financial and non-financial business support measures) and the factors that have negative impact on selfemployment (strict regulation of labour market, high taxes, bureaucratic barriers, etc.). The barriers mentioned above may vary depending on the level of the country, sector or region's development or company's type. With reference to the data of the European Entrepreneurship Cooperation (2004), the common barriers to self-employment development in the EU are as follows: regulation barriers such as market entrance administrative barriers, cultural and social barriers such as the fear of bankruptcy or the lack of knowledge and abilities necessary for business development, and financial-economic barriers such as insufficient access to the risk capital or funding of both young and longer-term business. To promote entrepreneurship in their countries the governments apply different measures in order to reduce the barriers to selfemployment development. The measures cover improvement of the general state of business sector including tax components, competitiveness policy, bankruptcy law, financial markets and availability of micro funding. According to the European Employment Observatory Review (2010), a range of policies and measures are in place to support and encourage self-employment. These include financial support, support services, training, mentoring and advice, measures to reduce bureaucracy and administrative burden, as well as favourable conditions for the self-employed in terms of the tax and social security regime.

The novelty of the analysed topic appears in the revelation of the main factors that promote and impede self-employment development. Up to now, the biggest part of the scientific research has been directed towards the identification of the factors that determine self-employment start-up success or failure (Dawson, et. al., 2012; Nziramasanga, et. al., 2009). That is why the aim of this article is the identification of the most significant and less significant factors that have the impact on self-employment development (duration) in Latvia.

The object of the article is the factors of macroeconomic environment of self-employment.

In order to fulfil the aim of the article, the following objectives have been defined: 1) to perform the analysis of the factors that have impact on self-employment duration; 2) to analyse current situation in business environment in Latvia; 3 ) 
to introduce the methodology of the research; 4) to present the results of empirical research.

The methods of the research include systematic and comparative analysis of the scientific literature as well as the reports of the World Bank and other institutions, and the method of expert evaluation.

\section{LITERATURE REVIEW: MACRO ENVIRONMENT FACTORS OF SELF-EMPLOYMENT DEVELOPMENT}

One of the main factors of self-employment distinguished in the scientific literature (Ees, Vuuren, 2011; Cueto, Mato, 2006; Wolff, Nivorozhkin, 2012) as the determinant of whether a self-employed person will develop his/her business and become an employer is favourable business environment, is generally formed by political organisations and the governments of the countries. Business-favourable decisions made in institutional environment are the determinants of selfemployment rate in the country.

One of the available measures of the institutional environment designed to promote self-employment is the provision of subsidies or non-financial support (Cueto, Mato, 2006; Kontos, 2003) such as training, consulting and monitoring. The evaluation of self-employment support financial measures and the impact of these measures on selfemployment development have earned insufficient attention in the scientific literature. The analysis of the literature has revealed that the newest research covers only the studies carried out in particular countries, i.e. the UK, New Zealand, Spain and Germany (Wolff, Nivorozhkin, 2012). The systematized results of the empirical research have revealed that not all programs (Meager, et. al., 2003) enable the achievement of the desired effect: the program applied in the UK did not show any significant effects on the creation of work places and it did not meet the expectations to increase the number of business units. However, the research carried out by Perry (2006) revealed the opposite results: the business start-up promotion program in New Zealand gave positive effects. Thus, it can be stated that the success of the implementation of self-employment promotion programs depends not only on the amount of the support. The target groups, personal motivation for business development and current economic situation are the factors that have to be considered as well.

The other studies researched self-employment growth/development considering the aspect of macroeconomic environment (Cueto, Mato, 2006; Nziramasanga, Lee, 2002). It is proposed that business cycles have impact on the fluctuation of self-employment rate, i.e. personal business development is restricted during the periods of economic recession. Thus, selfemployment development is negatively influenced by economic recession. On the other hand, economic revival contributes to business development and at the same time increases the attractiveness of self-employment. "The duration of selfemployment is negatively related to higher lending rates, increased imports and structural changes, but positively responds to growth." (Nziramasanga, Lee, 2002, p. 46).
Tax environment is considered to be another significant factor for business development. In general sense, high taxes have a negative impact on both self-employment start-up and duration (Ferede, 2013). In the scientific literature the taxrelated factors that have impact on self-employment are researched within:

- personal income tax;

- employer's social security contributions, payroll tax;

- benefit replacement rates.

Economic literature presents a limited number of studies on the evident benefits of personal income tax reduction for selfemployment. With reference to Blanchflower and Oswald (1998), the economists Kanbur (1981), Kihlstrom and Laffont (1983) were the first to identify the bidirectional effect of personal income tariffs on the number of self-employed. Later research (Blau,1987; Evans and Leighton, 1989, in the USA; Parker, 1996, and Robson ,1998, in the UK) established only positive correlation between the personal income tax and selfemployment rate, i.e. lower personal income taxes lead to a smaller number of the self-employed, and vice versa. The results of the research introduced above were confirmed by Cullen and Gordon (2002) who also propose that the personal income tax reduction negatively influences business activities, since a lower personal income tax tariff means lower business risk sharing with the government and this way makes selfemployment less attractive to risk averse people. Robson, Wren (1999) interpret these results explaining that higher tax tariffs motivate people to become self-employed due to more opportunities of tax evasion. Most scientists (Engström, Holmlund, 2006; Schuetze, 2000; Johansson, 2000; Apel, 1994) in their studies confirmed the hypothesis that the self-employed have more opportunities to hide their income. For instance, the scope of the shadow economy from self-employment made 5\% in the United Kingdom (Pissarides, Weber, 1989), 1\% - in Sweden (Apel, 1994), 2\% - in Finland (Johansson, 2000), 11\% in the United Kingdom (Lyssiotou, et. al., 2004).

For identification of the effect of personal income tax on self-employment, Robson (1998) proposes the classification of personal income tax into marginal and average due to the different impact of the previously mentioned types of the personal income tax on self-employment: high marginal tax rate (the amount of tax paid per additional dollar of income; as income rises, so does the tax rate) discourages people from doing business, since it decreases the income and thus acts as a self-employment barrier. On the contrary, high average tax rate encourages people to avoid taxes, making selfemployment a more attractive alternative than a hired work. Similar effect of personal income tax on self-employment was also revealed by Robson, Wren (1999): "lower marginal taxes affect individual efforts to seek for self-employment, but lower average taxes reduce the wish to circumvent the laws and evade taxes. Thus, individuals are encouraged to look for a hired work since the income from self-employment decreases after paying taxes".

Nevertheless, the marginal and average tax rates are not distinguished in all scientific studies while specifying the links between the self-employment and personal income tax. For 
instance, when researching the links between self-employment and personal income tax in the USA, Blau (1987) applies only the marginal tax tariff whereas Evans and Leighton (1989) engage the average tax tariff.

The results of the analysis of the scientific literature on the factors of macroeconomic environment having the impact on self-employment have enabled to systematize them and present graphically (Fig. 1). Although macroeconomic environment consists of numerous factor groups, such as technological, geographical, etc., the essential impact on selfemployment duration is made by the factors attributable to institutional and economic environment factor groups. From the factors of institutional environment, self-employment development is significantly influenced by tax tariffs and promotion measures (both financial and non-financial), while from the factors of economic environment the most influential ones are favourable economic situation in the country, low unemployment level and low wages for a hired work. It is obvious that psychological, sociological and demographical factors have complexive influence on business development. However, they are not the object of this article.

\begin{tabular}{|c|}
\hline Macroeconomic environment \\
\hline $\begin{array}{l}\text { Institutional factors: } \\
\text { - tax policy and tax tariffs, } \\
\text { - } \text { self-employment promotion, } \\
\text { - the position taken in the case of self-employment } \\
\text { Economics factors: } \\
\text { - unemployment level; } \\
\text { - wages in salaried employment; } \\
\text { - business cycle }\end{array}$ \\
\hline$\downarrow$ \\
\hline The duration (development) of self-employment \\
\hline$\downarrow$ \\
\hline $\begin{array}{l}\text { The level of self-employment in the country as a result } \\
\text { of the influence of the macroeconomic environment }\end{array}$ \\
\hline
\end{tabular}

Fig. 1. The factors that have impact on self-employment development (source: compiled by the author).

To summarise the results of the theoretical analysis, it can be stated that by following the best practice of the countries, where the level of entrepreneurship is high, the governments can direct the development of domestic self-employment into the right direction, at the same time improving tax and financial environment for business in their countries.

\section{CURRENT SitUATION OF LATVIAN BUSINESS ENVIRONMENT IN THE CONTEXT OF THE EU COUNTRIES}

With reference to the data of the World Bank (2014), Latvia takes the $24^{\text {th }}$ position among 189 economies worldwide by business establishment index. Since the article is aimed at the identification of the main factors of self-employment development, further analysis will include the evaluation of Latvian business environment conditions by particular indicators. The spheres of self-employment development with the lowest indicators are the following: paying taxes (rank 49), dealing with construction permits (rank 79) and getting electricity (rank 83). As it has been revealed by the analysis of the scientific literature, the retardment of business development can unambiguously be determined by an unfavourable tax system (Table I).

TABLE I

PAYING TAXES (SOURCE: COMPILED BY THE AUTHOR WITH REFERENCE TO THE WORLD BANK GROUP REPORT "DOING BUSINESS IN LATVIA", 2014)

\begin{tabular}{|l|l|}
\hline Indicator & Value \\
\hline Payment (number per year) & 7 \\
\hline Time (hours per year) & $\mathbf{2 6 4}$ \\
\hline Profit tax (percent) & 4.9 \\
\hline Labour tax and contributions (percent) & $\mathbf{2 7 . 3}$ \\
\hline Other taxes (percent) & 3.7 \\
\hline Total tax rate (percent of profit) & 35.9 \\
\hline
\end{tabular}

The data presented in Table I show that the high labour taxation is a major obstacle for self-employment development. The $27.3 \%$ social insurance contribution tariff applied in Latvia is higher in comparison with other EU countries. For instance, in Slovenia social insurance contribution tariff is equal to $18.2 \%$ and in Bulgaria it is equal to $20.2 \%$. The position taken by Latvia in comparison with other EU countries in respect to the tax base for business environment can be seen in Fig. 2.

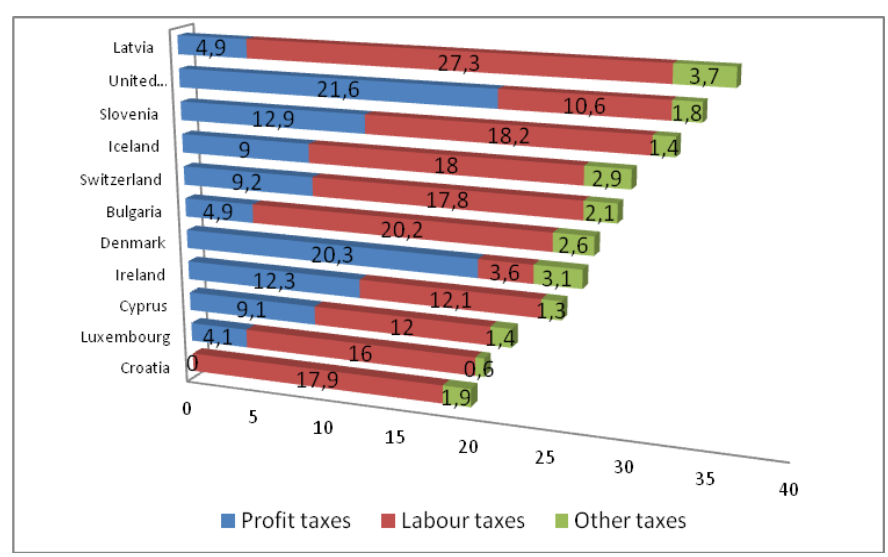

Fig. 2. Total tax rate, percentage in EU \& EFTA (Source: Paying Taxes 2014: the global picture - a comparison of tax systems in 189 economies worldwide).

As it can be seen from Fig. 2, Latvia takes a rather high position (11 ${ }^{\text {th }}$ position) among 32 EU and EFTA (European Free Trade Association) country groups considering the general tax rate in the country.

The data for the year 2014 show that Latvian labour market is charged the highest percentage while profit taxes are much lower. When comparing Latvian business tax environment tariffs with the ones in other Baltic States, it has been established that Latvia takes the position of the leader of the lowest tax tariffs whereas Estonia and Lithuania lag behind in respect of making labour and profit taxes favourable for business (Fig. 3). 


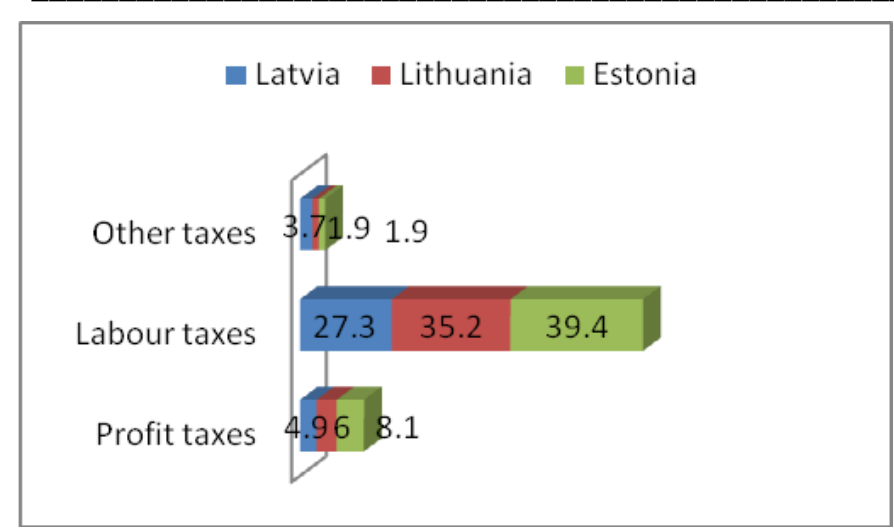

Fig. 3. Total tax rate, percentage in the Baltic States (Source: Paying Taxes 2014: the global picture - a comparison of tax systems in 189 economies worldwide).

The practice when employers, seeking to evade paying social insurance contributions or other taxes, engage the services of the self-employed is wide-spread in the European Union, i.e. for service provision, a person has to obtain a business licence. Such activity is referred to as "depended self-employment"; it shows the distorted situation in the labour market, i.e. the level of self-employment seems to increase, although this increase is determined by the reasons different from the ones that determine entrepreneurship. The possible solution to the latter problem lies in lower tariffs of the social insurance contributions.

Business development needs funding. However, the selfemployed people usually lack the necessary external funding. With reference to the data of 2013, the most popular source of business funding was bank loans. In 2010, the total amount of the bank loans for business in Latvia made $6.8 \%$ of the GDP of the country while the EU average was only $5.65 \%$ of GDP. Other, less popular funding measures include guarantees, venture capital and particular business promotion programs (Barriers of international cooperation for SMEs in Latvia, Estonia, Finland and Sweden, 2013).

After the crisis, the number of own account workers (or self-employed without employees) did not return to previous positions, i.e. with reference to the data of 2013, the number of the self-employed in Latvia was 54.9 thousand people while in 2007 this number was 57.6 thousand people.

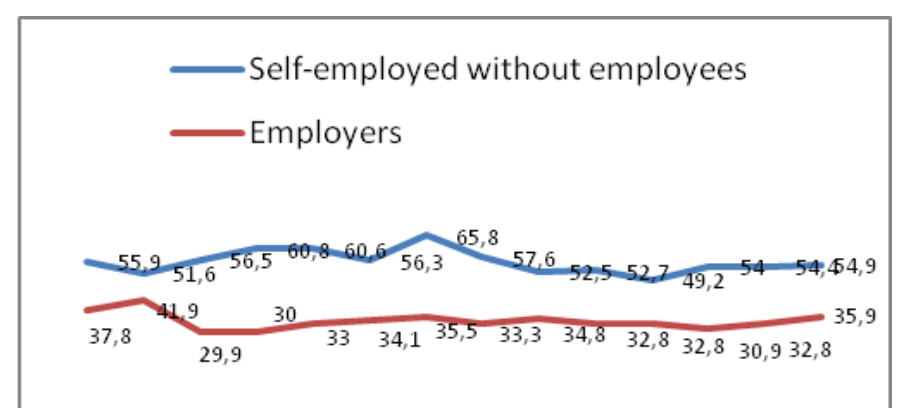

20002001200220032004200520062007200820092010201120122013

Fig. 4. The dynamics of the number of the employers (thousand people) and self-employed without employees (thousand people) during 2000-2013 (compiled by the author with reference to Eurostat database).
With reference to the European Employment Observatory Review (2010), the measures applied for self-employment promotion have not brought any positive effects. In Latvia, for example, the government has reversed some of the tax advantages of self-employment in the process of budget consolidation. In particular, the self-employed now face the rate of $26 \%$, which is the same as for other workers (previously it was 15\%). Summarising the data on selfemployment environment in Latvia it can be stated that tax rates can be considered rather favourable, and in this respect Latvia takes the $11^{\text {th }}$ position among 30 European countries, but for the same reason the significant part of employers engage the services of the self-employed to evade social insurance contributions, i.e. employers force the selfemployed person to perform work under business licence. As a result, the statistical data on the self-employment rate in the country are distorted.

\section{The Methodology OF THE RESEARCH}

The empirical research was based on the method of expert evaluation which enabled to identify the prospects of selfemployment development without hired employees and to rank the policy measures that are significant for both a person who has already made the decision to become self-employed and a self-employed person who has already been operating in the market.

The expert evaluation is considered to be a fast developing scientific-practical discipline aimed at a systematic organization, coding, structural processing, logical and mathematical interpreting of the data collected, while surveying a person - an expert. The expert evaluation is treated as a generalized opinion of a group of experts with particular knowledge, experience and intuition. The method of expert evaluation is the procedure which enables to combine the opinions of individuals and make a general decision. A person with the knowledge and experience in a particular sphere can be considered as an expert with well-developed intuition, thus, he/she can be involved in the research as a source of qualitative information (Augustinaitis, et al., 2009). The author of this article is of the opinion that the method of expert evaluation is one of the most effective methods for the collection and analysis of the primary data while seeking to have an insight in the real situation of the researched object and to detect problem areas.

The research was carried out in the following stages:

1) translation of the questionnaire into Latvian (the questionnaire used for the research of self-employment in Lithuania was applied); 2) selection of experts; 3) experts' survey using the tools of e-questionnaire and an interview; 4) data processing with SSPS software package; 5) interpretation of answers and making conclusions. Businessmen with business experience not less than five years and the members of the Board of Latvian Chamber of Commerce and Industry who know Latvian business environment peculiarities well were selected as experts. The total number of experts was 5 people. With reference to Augustinaitis et al. (2009), in order to retain reliability and accuracy of the research, it is 
recommended to include not fewer than five experts. The experts had to evaluate the statements by the Likert scale where 1 point means that they completely disagree with the statement, so the factor or policy measure has the minimal impact on self-employment; 5 points mean that they completely agree with the statement, so the factor has the strongest impact on self-employment. The survey was carried out from 25 November to 19 December 19, 2013.

The factor is considered to be significant if the mean numerical value falls into the interval from 4 to 5 , less significant if the mean value falls into the interval from 3.4 to 3.9 , and insignificant if the mean value is 3.3 and lower.

Limitations of the research. Although the Latvian Chamber of Commerce and Industry unites a big number of entrepreneurs, the number of experts who agreed to participate in the research was rather small due to the heavy workload of the entrepreneurs or their disregard of the request to contribute to the research. Two of the experts, who had agreed to contribute, were interviewed face-to-face, the other three experts were interviewed via e-platforms. Some difficulties were also caused by the fact that the author was interviewing the entrepreneurs of the foreign country.

\section{THE RESUltS OF THE EXPERT EVALUATION}

The results of the expert evaluation revealed that the questions formulated for the survey reflected the researched dimension with sufficient accuracy (Cronbach alpha coefficient is equal to 0.76 ). The main factors that promote the self-employment development and employment of other people, with reference to the opinion of the experts, are acquisition of higher skills because a single person cannot be sufficiently competent in all fields including finance, production or other spheres that require specific knowledge (mean rank value is equal to 4.20; mean value is equal to 4.20) and increasing demand for the products/services, expansion into new markets (mean rank value is equal to 3.70, mean value is equal to 4.20). The other three factors presented in the questionnaire have been considered as less significant for the self-employment development: peculiarities of country or EU's business funding availability (in order to get the funding, it is necessary to employ other people) (mean rank value is 2.30 , mean value is 3.40 ), the fear to lose a skilled person who has previously been paid on the basis of copyright agreement, or other types of payment were engaged (mean rank value is 2.40, mean value is 3.40 ), and taking advantage of the economic situation (skilled employees agree to work for much lower wages, lower rent, etc., due to the increased unemployment level (mean rank value is 2.40 , mean value is equal to 3.40$)$.

The main factors that impede the self-employment development in Latvia have been ranked by their significance in Table II-I, Table II-II and Table II-III.
TABLE II-I

RANKING OF FACTORS THAT IMPEDE SELF-EMPLOYMENT DEVElopment IN LATVIA By SigNifiCANCE (SOURCE: COMPILED BY THE AUTHOR WITH REFERENCE TO THE RESULTS OF THE EMPIRICAL RESEARCH)

\begin{tabular}{|l|l|l|}
\hline The most significant factors & Mean Rank & Mean \\
\hline $\begin{array}{l}\text { Unfavourable economic situation in the } \\
\text { country (decreased consumption) }\end{array}$ & 13.7 & 4.6 \\
\hline $\begin{array}{l}\text { Taxes for employing another person are } \\
\text { too high (high labour force taxation) } \\
\text { and additional taxes for establishing an } \\
\text { enterprise (profit, VAT, excise, } \\
\text { property, land and other taxes) }\end{array}$ & 13.3 & 4.6 \\
\hline $\begin{array}{l}\text { Difficulties in finding skilled and } \\
\text { reliable labour force }\end{array}$ & 12.5 & 4.4 \\
\hline $\begin{array}{l}\text { Lack or inaccessibility of the capital } \\
\text { necessary for business establishment, } \\
\text { i.e. imperfections of the current bank } \\
\text { loan system }\end{array}$ & 10.6 & 4 \\
\hline Legal - administrative barriers & 10.6 & 4 \\
\hline $\begin{array}{l}\text { Fear to take responsibility for another } \\
\text { employee, i.e. the risk that the business } \\
\text { will fail to maintain a hired employee }\end{array}$ & 10.6 & 4 \\
\hline
\end{tabular}

TABLE II-II

RANKING OF FACTORS THAT IMPEDE SELF-EMPLOYMENT DEVELOPMENT IN LATVIA BY SigNIFICANCE (SOURCE: COMPILED BY THE AUTHOR WITH REFERENCE TO THE RESULTS OF THE EMPIRICAL RESEARCH)

\begin{tabular}{|l|l|l|}
\hline Less significant factors & Mean Rank & Mean \\
\hline Competition in the market is too intense & 8.90 & 3.8 \\
\hline $\begin{array}{l}\text { EU or country's support on the } \\
\text { condition that another person is } \\
\text { employed does not ensure business } \\
\text { success }\end{array}$ & 8.70 & 3.8 \\
\hline Customers' insolvency & 8.60 & 3.8 \\
\hline Lack of marketing knowledge & 6.9 & 3.4 \\
\hline Lack of management competence & 6.9 & 3.4 \\
\hline
\end{tabular}

TABLE II-III

RANKING OF FACTORS THAT IMPEDE SELF-EMPLOYMENT DEVElOPMENT IN LATVIA BY SigNIFICANCE (SOURCE: COMPILED BY THE AUTHOR WITH REFERENCE TO THE RESULTS OF THE EMPIRICAL RESEARCH)

\begin{tabular}{|l|l|l|}
\hline Insignificant factors & Mean rank & Mean \\
\hline $\begin{array}{l}\text { The procedure of business } \\
\text { establishment is too complicated }\end{array}$ & 6.5 & 3 \\
\hline $\begin{array}{l}\text { Lack of time due to the caring about } \\
\text { little children and household }\end{array}$ & 6.5 & 3.2 \\
\hline $\begin{array}{l}\text { Lack of family's support, fear to } \\
\text { combine work and family life }\end{array}$ & 6.10 & 3.2 \\
\hline Distrust in employees & 5.90 & 3 \\
\hline
\end{tabular}

As it can be seen from the data presented in Table II-I, the main barriers to the self-employment development are high taxes and unfavourable economic situation (the research was carried out at the end of 2013, when the economics was still lower than the pre-crisis level) while such factors as complicated procedure of business development or distrust in employees, according to the experts, are not significant for self-employment development. 


\section{CONCLUSION AND DISCUSSIONS}

Constant academic and political interest in the determinants of self-employment determines the attitude that selfemployment is a source of economic growth. Selfemployment and the creation of work places are the main European policy elements that promote economic growth and employment. Financial and economic crisis has negatively influenced the self-employed people. Thus, the governments have to respond properly by applying efficient measures for self-employment development (creation of a microenterprise). In general sense, the rate of self-employment in EU countries depends on the conditions of the labour market, including labour market flexibility, the system of unemployment benefits, childcare system and the barriers for business start-up and development. Different policy of institutional environment also determines the differences of the rate of self-employment in the EU countries. Although the statistical data on the number of the employers and the selfemployed in Latvia during the period of 2001 - 2013 did not show the emergence of financial crisis (Fig. 4), the EU member-countries (including Latvia) still focus on the policy documents and strategies of the employment dimension in terms of job creation. According to the European Foundation for the Improvement of Living and Working Conditions (2011) entrepreneurship and business development is almost as much in focus for self-employment, which is not the case for the two other target areas, either the hiring of the first employee or hiring additional employees.

The main conclusion of the empirical research on selfemployment development in Latvia is that institutional factors influenced by the governmental decisions can be attributed to the factors that have the biggest impact on self-employment development. In order to encourage the self-employed people to establish enterprises and export their production the government of the country should mitigate the regulation of the labour market.

\section{REFERENCES}

Apel, M. (1994). An expenditure-based estimate of tax evasion in Sweden. Essays on Taxation and Economic Behaviour. Economic Studies, 18.

Augustinaitis, A., Rudzkiene, V., Petrauskas, R., A., Dagyte, I., Martinaityte, E., Leichteris, E., Malinauskiene, E., Visnevska, V., Žilioniene, I. (2009). Lietuvos e. valdžios gairès: ateities įžvalgų tyrimas, Vilnius, Mykolo Romerio Universitetas.

Barriers of international cooperation for SMEs in Latvia, Estonia, Finland, and Sweden. Retrieved Oct. 19, 2014, from: http://www.liaa.gov.lv/files/liaa/attachments/shm_barriers_for_intern ational_cooperation_for_smes_updated_version_final.pdf

Blanchflower, D. G., Oswald, A. J. (1998). What makes an entrepreneur? Journal of Labor Economics, 16 (1), 26-60. http://dx.doi.org/10.1086/209881

Blau, D. M. (1987). A time-series analysis of self-employment in the United States. Journal of Political Economy, 95 (3), 445-467. http://dx.doi.org/10.1086/261466

Cullen, J. B., Gordon, R. H. (2002). Taxes and entrepreneurial activity: theory and evidence for the U. S. NBER Working Paper, 9015, p. 58.

Cueto, B., Mato, J. (2006). An analysis of self-employment subsidies with duration models. Applied economics 38:1, 23-32. http://dx.doi.org/10.1080/00036840500367542

Dawson, C., Henley, A., Latreille, P. (2012). Individual motives for choosing self-employment in the UK: Does region matter? Regional Studies, 48:5, 804-822. http://dx.doi.org/10.1080/00343404.2012.697140
Engström, P., Holmlund, B. (2006). Tax evasion and self-employment in a high-tax country: evidence from Sweden. Working Paper, no. 1763, p. 21.

Eurobarometer (2009). No 283. Entrepreneurship in the EU and beyond. Retrieved Oct. 19, 2014, from: http://ec.europa.eu/public_opinion/flash/fl_283_en.pdf

European Entrepreneurship Cooperation (2004). Barriers to entrepreneurship and business creation. Retrieved Sep. 19, 2014, from: http://www.adrimag.com.pt/downloads/cooperacao/Barriers\%20entre preneurship\%20and\%20business\%20creation.pdf

European Employment Observatory Review. Self-employment in Europe. Retrieved Oct. 19, 2014, from: http://www.eurofound.europa.eu/ emcc/erm/studies/tn1108034s/tn1108034s_3.htm

European Foundation for the Improvement of Living and Working Conditions (2011). Public measures to support self-employment and job creation in one person and micro enterprises. Retrieved Oct. 19, 2014, from: www.eurofound.europa.eu

Eurostat database. Self-employment by sex, age and economic activity. $\begin{array}{llll}\text { Retrieved } & \text { Sep. } & 19, & \text { 2014, }\end{array}$ http://epp.eurostat.ec.europa.eu/portal/page/portal/statistics/search_da tabase

Evans, D. S., Leighton, L. S. (1989). Some empirical aspects of entrepreneurship. The American Economic Review, 79, 3, 519-535.

Johansson, E. (2000). Determinants of self-employment duration - evidence from Finnish micro-data. Essays on Economics and Business Administration, Helsinki, Ekonomi och Samhäll, 85, p. 30

Ferede, E. (2013). Tax progressivity and self-employment: evidence from Canadian provinces. Small Business Economics 40, 141-153. http://dx.doi.org/10.1007/s11187-011-9350-7

Kontos, M. (2003). Self-employment policies and migrants' entrepreneurship in Germany. Entrepreneurship \& Regional Development: An International Journal, $15, \quad 2, \quad 119-135$. http://dx.doi.org/10.1080/0898562032000075131

Lyssiotou, P., Pashardes, P., Stengos, T. (2004). Estimates of the black economy based on consumer demand approaches. The Economic Journal, $\quad 114, \quad 622-640 . \quad$ http://dx.doi.org/10.1111/j.14680297.2004.00234.x

Meager, N., Bates, P. and Cowling. M. (2003). An Evaluation of Business Start-up Support for Young People. National Institute Economic $\begin{array}{lllr}\text { Review } & 186 & \text { (1): } & \text { 59-72. }\end{array}$ http://dx.doi.org/10.1177/002795010300100111

Nziramasanga, M. T., Bhattacharjee, S., Lee, M. (2009). Viability of selfemployment. Journal of Development Studies 45, 7, 1070-1092. http://dx.doi.org/10.1080/00220380902811033

Nziramasanga, M., Lee, M. (2002). On the Duration of Self-Employment: The Impact of Macroeconomic Conditions. The Journal of Development Studies, 39:1, 46-73. http://dx.doi.org/10.1080/00220380412331322661

Parker, S. C. A. (1996). Time-series model of self-employment under uncertainty, Economica, 63, 459-475.

Perry, G. (2006). Are Business Start-up Subsidies Effective for the Unemployed: Evaluation of Enterprise Allowance. Proceedings of Work, Pensions and Labour Economics (WPEG) Conference, University of Kent, Canterbury.

Pissarides, C.; Weber, G. (1989). An expenditure-based estimate of Britain's black economy. Journal of Public Economics, 39, 17-32. http://dx.doi.org/10.1016/0047-2727(89)90052-2

Remeikiene, R.; Startiene, G. (2011). The institutional environment factors of self-employment in transition economies: the case of Lithuania. Changes in Social and Business Environment: proceedings of the 4th international conference, p. 186-194.

Robson, M. T. (1998). The rise in self-employment amongst UK males. Small Business Economics, 10, 199-212. http://dx.doi.org/10.1023/A:1007990921394

Robson, M. T., Wren, C. (1999). Marginal and average tax rates and the incentive for self-employment. Southern Economic Journal, 65, 757773. http://dx.doi.org/10.2307/1061274

Startiene, G., Remeikiene, R. (2013). Business environment conditions in more advanced transition economies. European Journal of Business and Social sciences 1 (12), p. 216-232.

Schuetze, H. J. (2000). Taxes, economic conditions and recent trends in male self-employment: a Canada-US comparison, Labour Econ, 7 (5), 507-544. http://dx.doi.org/10.1016/S0927-5371(00)00012-9 
van Es, V., van Vuuren, D. J. (2011). A decomposition of the growth in selfemployment. Applied Economics Letters18:17, 1665-1669. http://dx.doi.org/10.1080/13504851.2011.558471

Vejsiu, A. (2011). Incentives to self-employment decision in Sweden. International Review of Applied Economics, 25:4, 379-403. http://dx.doi.org/10.1080/02692171.2010.511170

Wolff, J., Nivorozhkin, A. (2012). Start Me Up: The Effectiveness of a Selfemployment Programme for Needy Unemployed People in Germany. Journal of Small Business \& Entrepreneurship, 25:4, 499-518. http://dx.doi.org/10.1080/08276331.2012.10593586

World Bank Group (2014). Doing Business in Latvia. Retrieved Oct. 18 , 2014, from: http://www.doingbusiness.org/data/exploreeconomies/ latvia/\#paying-taxes

World Bank (2014). Paying Taxes 2014: The global picture. A comparison of tax systems in 189economies worldwide. Retrieved Oct. 19, 2014, from:http://www.doingbusiness.org/ /media/GIAWB/Doing\%20Busi ness/Documents/Special-Reports/Paying-Taxes-2014.pdf

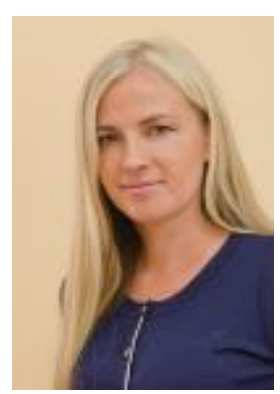

Rita Remeikiene received the $\mathrm{PhD}$ degree in economics from the Kaunas University of Technology in 2012 after defending the PhD thesis on the topic "The Factors of Self-Employment in Transition Economies". Her main research areas include business environment analysis, selfemployment factors and processes, labour market problems, shadow economy and outsourcing.

Since 2013, she has been an Associate Professor with the Kaunas University of Technology and the Mykolas Romeris University. She is also a seminar lecturer with Ltd "Inlinen".

She was a Senate Administrator of the Kaunas University of Technology. Address: Mykolas Romeris University, Ateities str. 20, Vilnius, Lithuania. $\mathrm{T}:+37061624114$

E-mail: rita.remeikiene@mruni.eu 